\title{
The Value of a Book: Beyond the Price
}

\section{Shannen Shott}

'School of Library and Information Studies, University of Alberta, sshott@ualberta.ca

To Cite:

Shott, S. (2021). The value of a book: Beyond the price. [Special Issue]. Pathfinder: A

Canadian Journal for Information Science Students and Early Career Professionals, 2(1), 41-51. https://doi.org/10.29173/pathfinder43

\section{Abstract}

This research comments on the historical and current trends of special collection libraries and the ways in which their collection policies reflect priorities of protecting certain voices over others, thus assigning a value to those books which are sought after. While book value has been discussed extensively, most of the literature has not taken into account the significance of collection policies, which is a gap that my research aims to address. The methodology includes a literature review of the different ways in which book value is determined and an examination of the collection policy documents of twenty North American special collection libraries. This examination, accomplished via coded data analysis, will determine how these documents reflect the historical and current priorities of special collections and how they subsequently assign value to books. The results of this analysis indicate a consistent commitment to acquiring materials that build on existing collection strengths, as well as a prioritization of locality as it relates to potential additions. Furthermore, the limited inclusion for marginalized communities in collection policies suggests a need to discuss the future direction of documentation as it relates to recognizing the value of marginalized voices.

Keywords: Special collections, collection policy development, value

\section{$\mathrm{S}$} pecial collections libraries, which serve to make old and rare books available under conditions that protect and preserve the materials, serve a distinct role in defining which books are valuable. The value of a book signifies more than the price, and my research explores the different ways a book is valued and under what circumstances, particularly in the context of special collections. This paper aims to answer the following questions: 
- What do the collection policies of special collections libraries suggest about how they assign value to books?

- What do these collection policies suggest about current and growing trends in special collections development?

While book value has been discussed extensively in terms of pricing and its research value, this paper aims to address the gap regarding policies in this discussion. Collection policies play a powerful role in reflecting the priorities of the special collection, specifying what it aims to acquire and formally recognizing the value of that material. This research was conducted via coded data analysis of collection policies from twenty North American special collections. The results of this analysis indicate a consistent commitment to acquiring materials that build on existing collection strengths, as well as a prioritization of locality. This paper will also discuss concerns regarding marginalized voices in special collections and the limited inclusion of marginalized communities in policies.

\section{Literature Review}

The literature that addresses book value indicate three main types: monetary, sentimental, and research. Monetary value primarily refers to the price of a book, often in the context of the book market. Brunet and Shiflett (1992) have designated desirability, scarcity, condition as the three factors in determining the price of a book. In response to the popular notion that the age of a book directly correlates to its price in the book trade, Dyal (1995) asserts that age is hardly the only factor, or even an important one. According to Dyal, the most important factor is demand, followed by condition and completeness. As this paper will demonstrate, the nuances behind book value are subjective to the contexts of the books in question and their relationship with historical or contemporary environments.

The driving force behind sentimental value is the relationship between a book and a person or group of people. According to Brunet and Shiflett (1992), "People want to believe with an almost religious faith that books are valuable" (p. 87). They refer to the people who are convinced that their old books can be converted into some monetary value. Brunet and Shiflett suggest that librarians have yet to fully legitimize the needs of "those who want to know how much their grandfather's books are worth" 
(p. 86). In the interest of working to legitimize those needs, this paper supports the sentimental value that many old books carry.

Research value refers to the intellectual value that a book provides as it relates to the research objectives of an institution or the wider scholarly community. Scott (2010) criticizes the strategy of 'collecting to strength', which has been adopted by many special collections. By collecting to strength, libraries were valuing research over teaching, garnering international interest, and vying to be the envy of rival collections (Scott, 2010). Although the strategy has its merits, such as bolstering support for particular research areas, Scott calls attention to four gambles: (1) that the materials will remain affordable over time; (2) that the strength is unique; (3) that the collection will continue to offer fresh research potential; (4) and that the collection area will be a worthy long-term investment for future generations.

Underlying nearly every discussion about collection management is the matter of what material is being pushed to the margins. Galbraith (2014) encourages libraries to take the risk in exploring these margins and discover which materials are being ignored "but may have value further down the road and thus deserve to be preserved" (p. 331). In particular, special collections are in a unique position to preserve materials for future generations; Galbraith makes the point that the materials that are pushed aside "are ephemeral and in danger of being lost" (p. 331). For this reason, this paper will be considering which material is excluded from recognition in collection policies. According to Hawley (2016), "Objects have meaning when they are used, not merely because of the continuity of their existence" (p. 8). Hawley goes on to argue that books therefore can be seen as meaningless if there is no level of interaction wherein the book is used and shared, building new memories into the object.

\section{Methods}

The design of this research project's data collection is centered around an analysis of collection policies. Collection policies were gathered from the websites of twenty North American special collection libraries. These policies were then coded for the categories of 'active acquisition', which include any materials specified as being currently sought out by the library to add to their collection, and 'collection strengths', which include any areas of that were specified by the policy as a strength in the 
collection. The results of this coding for each individual policy were compared in order to locate patterns across the different libraries. These patterns were then cross-referenced with existing literature about book value and special collections in order to determine how the current patterns matched with previous trends.

\section{Results}

Figure 1

Subject matters specified in collection strengths

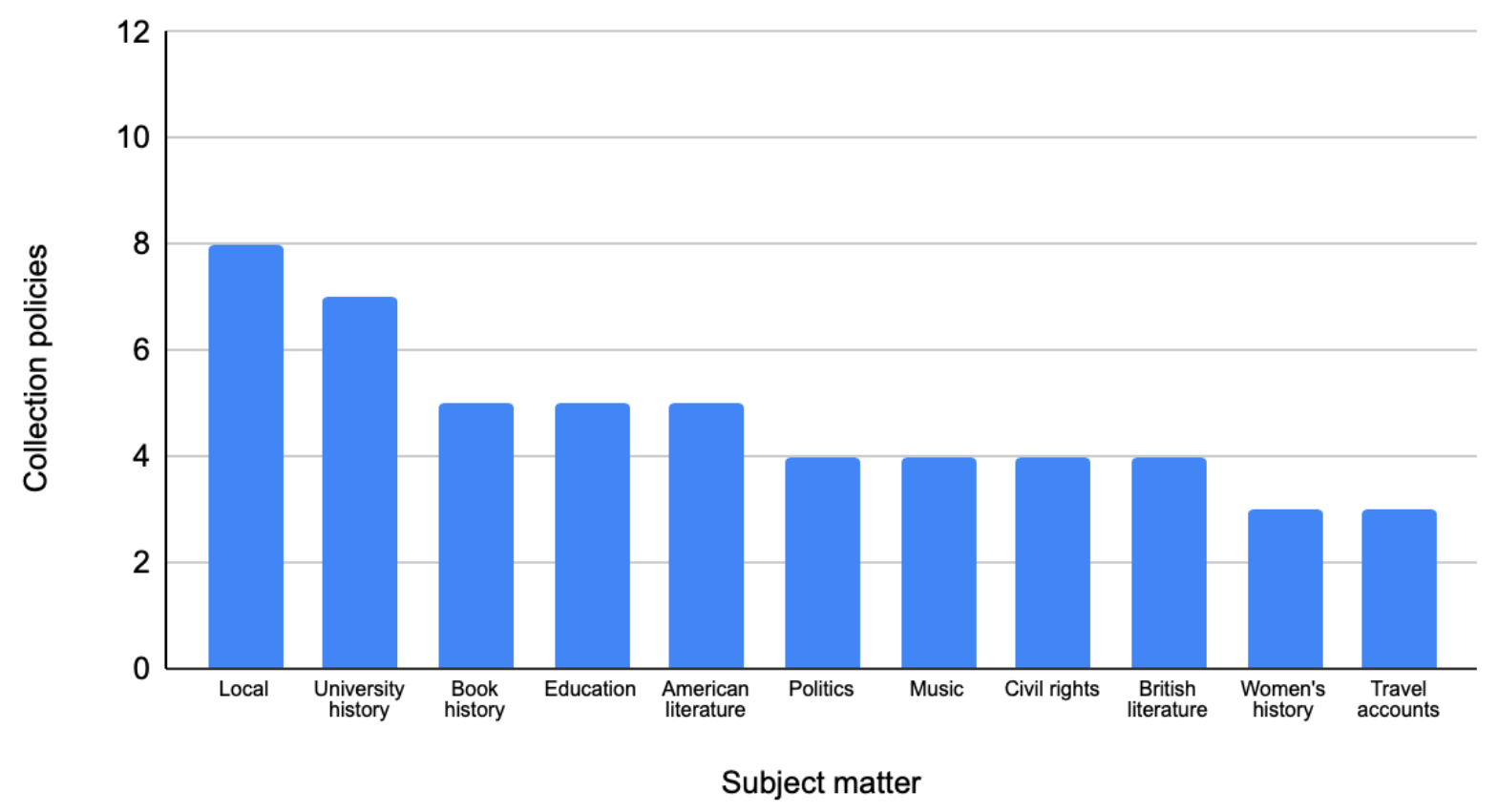


Figure 2

Subject matters specified in active acquisition

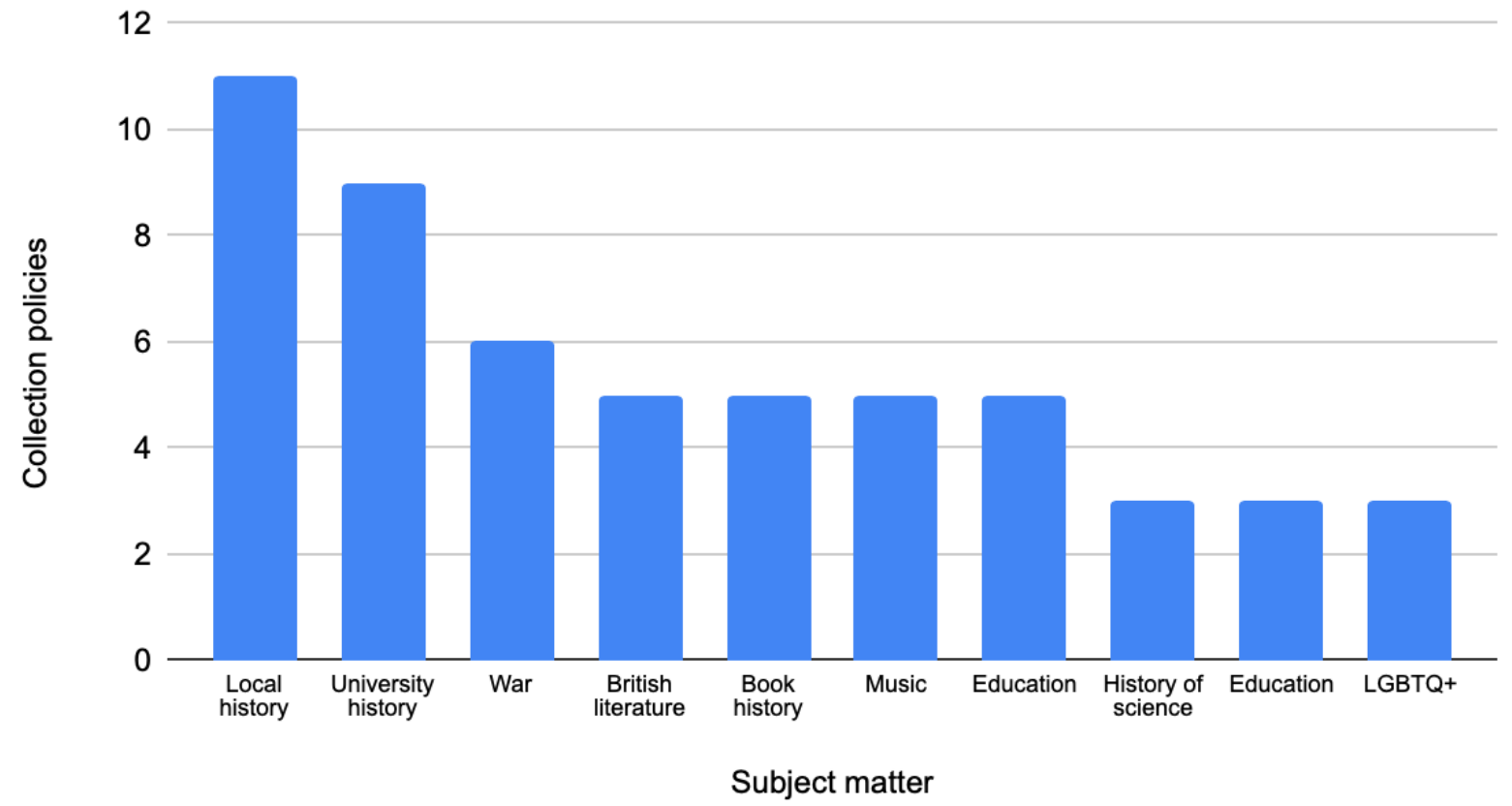

Figure 3

Writers specified in active acquisition

10

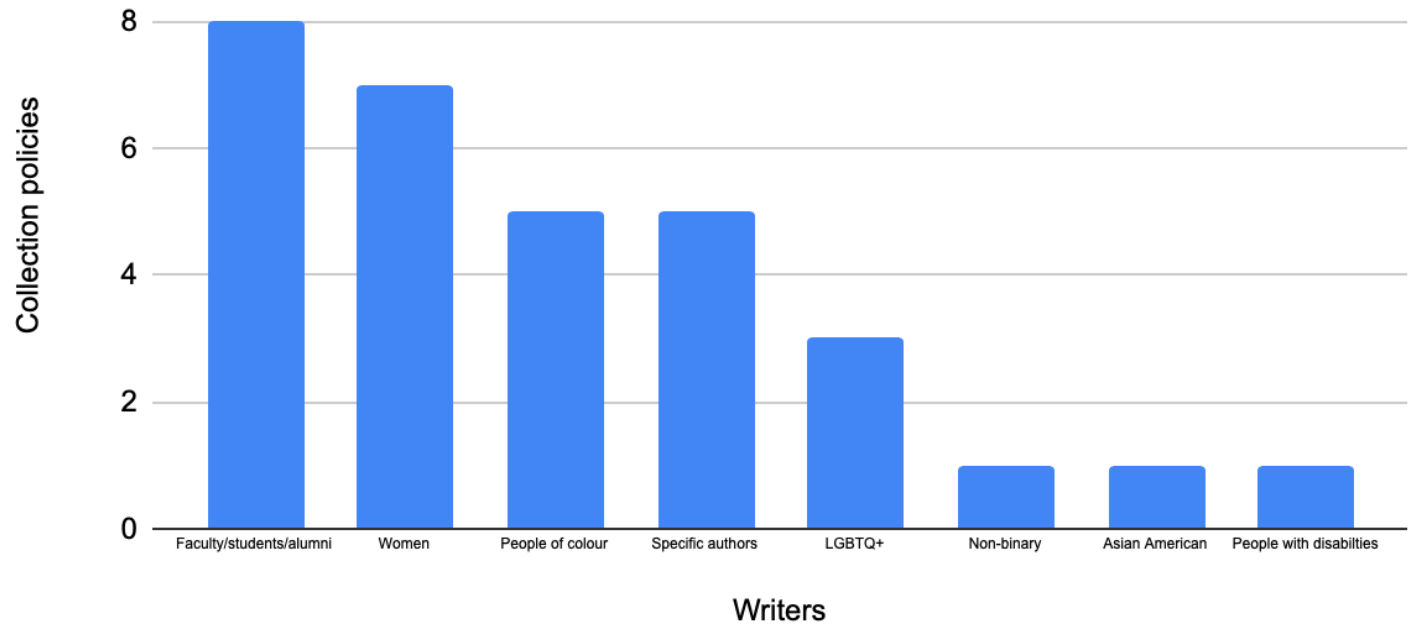

Pathfinder: A Canadian Journal for Information Science Students and Early Career Professionals (C)The Author(s) 2019. 


\section{Discussion}

Many of the collection policies list unique materials in both active acquisition and collection strengths, related to their institution's history, geography, and donor collections. Such unique materials include subjects such as missionary activities, history of psychoactive substances research, insect eradication, cartography, and many more. Therefore, patterns of repeated subject matters are notable because they represent a common thread across the distinct natures of the twenty special collections analyzed for this research project.

The most frequently specified subject matter in the collection policies is local history, followed closely by university history. In most rare book collections, a large portion of the material will address the local history, giving it a high research value in terms of locality (Potter \& Holley, 2010). This suggests that another type of book value might be that of local value. Considering the established importance of local and university history, it is not surprising to find that the most frequently specified group of writers in active acquisition is that of faculty, students, and alumni. The popularity of women and people of colour is an interesting trend in light of Scott's (2010) article, where he noticed the growing emphasis in "some areas of African-American studies and women's and gender studies" as a push by younger faculty to get library support for their areas of interest during the twentieth century (p. 51).

The categories of "non-binary," "Asian American," and "people with disabilities" were included in Figure 3 because they all originated from a single collection policy. As such, these categories stood out against the backdrop of more vague generalizations around inclusion. The inclusion of specific marginalized communities is far more powerful than generalized statements about supporting diversity in recognizing the value of those communities and the library's commitment to collecting their materials. Acknowledgement of these communities within the official documentation of a collection policy opens the door to the communities garnering recognition not only within special collections, but in the wider academic institutional space as well (Hawley, 2016).

Of the twenty collection policies, nine specified that they were collecting to strength, seven did not specify that they were collecting to strength, and four policies implied, but did not specifically acknowledge, that they were collecting to strength. 
Although the strategy has been argued to be outdated and risky (Scott, 2010), collecting to strength is still very much a current and ongoing strategy of choice in special collections.

\section{Conclusion}

The findings of this research reveal that the strategy of collecting to strength is still a prominent approach to collection development in special collections. The evidence that collecting to strength is an ongoing trend suggests that the value of a book in special collections lies in its relationship to the existing collection. The frequency of local history and campus history in the data coding establishes locality as a fourth type of book value. The specified identities of non-binary, Asian Americans, and people with disabilities in one of the collection policies demonstrates the potential that these policies have for recognizing the value of marginalized communities. By listing specific marginalized groups in their policy, a library demonstrates their shift away from colonial and canonical works towards the goal of a more inclusive collection.

The results of this study could be expanded by increasing the data size and examining more collection policies from North American special collection libraries, as well as speaking directly to the librarians to gather more context for the policies. Further studies could be conducted around analyzing what material is in special collections and how collection strengths are being defined in collection development policies. There remains a wealth of research to be done on the topic of special collections and their collection development, which will expand our understanding of where special collections stand today and what their direction is for the future. 


\section{References}

Brunet, P.J., \& Shiflett, L. (1992). Out-of-print and antiquarian books: Guides for reference librarians. $R Q, 32(1), 85-100$. DOI: 10.2307/25829197

Dyal, D.H. (1985). What old books are worth: When price, not preservation, is paramount, it's best to set 'em straight. American Libraries, 16(11), 774-6. https://login.ezproxy.library.ualberta.ca/login?url=https://search.ebscohost.com/lo gin.aspx?direct=true\&db=edscal\&AN=edscal.8569442\&site=eds-live\&scope=site

Galbraith, S.K. (2014). Thinking about collection development in special collections. In B. Albitz, C. Avery, \& D. Zabel (Eds.), Rethinking collection development and management (pp. 323-33). Libraries Unlimited.

Hawley, E.H. (2016). Reflections on the meaning of objects. In A. Hirshon, R.H. Jackson \& M.A. Hubbard (Eds.), Forging the future of special collections (pp. 310). Neal Schuman.

Potter, S. \& Holley, P. (2010). Rare materials in academic libraries. Collection Building, 29(4), 148-153. DOI: 10.1108/01604951011088880

Scott, P. (2010). Focus versus breadth in special collections acquisitions. Against the Grain, 22(2), 50-3. DOI: 10.7771/2380-176X.5508 


\section{Collection Policies}

Amherst College. (n.d.). Archives \& special collections collection development policy. https://www.amherst.edu/library/archives/collectiondevelopment

George Washington University. (n.d.). Collection development policy: Education.

https://library.gwu.edu/sites/default/files/scrc/Education collection development policy.pdf

George Washington University. (n.d.). Collection development policy: Kiev Judaica.

https://library.gwu.edu/sites/default/files/scrc/Kiev collection development policy . pdf

George Washington University. (n.d.). Collection development policy: Labor.

https://library.gwu.edu/sites/default/files/scrc/Labor collection development poli cy.pdf

George Washington University. (n.d.). Collection development policy: Washingtoniana. https://library.gwu.edu/sites/default/files/scrc/Washingtoniana collection develop ment policy2016.pdf

James Madison University. (n.d.). Special collections - Collection development policy. https://www.lib.jmu.edu/policies/special-collection-development/

NYU Libraries. (n.d.). Special collections: Collection development policy. https://guides.nyu.edu/speccol/coll-dev-policy

Purdue University Libraries. (n.d.). Virginia Kelly Karnes archives and special collections research center - Collection development policy.

https://www.lib.purdue.edu/sites/default/files/spcol/archives collection developm ent policy.pdf

Smith College Libraries. (n.d.). Collection development

strategy. https://libraries.smith.edu/special-collections/about/collectiondevelopment-strategy

United States Department of Agriculture. (n.d.). Collection development policy. https://specialcollections.nal.usda.gov/collection-development-policy

University of Alberta. (n.d.). Bruce Peel special collections library - collection policy. https://www2.library.ualberta.ca/2015assets/about/BPSCcollectionpolicy.pdf 
University of Arizona Libraries. (n.d.). Collection development policy. http://speccoll.library.arizona.edu/collection-development-policy

University of Arkansas Libraries. (n.d.). Collection development policy. https://libraries.uark.edu/specialcollections/about/collection-developmentpolicy.pdf

University of British Columbia. (n.d.). General guidelines for collecting and list of major collections: Print and archival. https://rbsc.library.ubc.ca/files/2013/07/acquisitionspolicypublicweb1.pdf

University of Denver. (n.d.). Special collections and archives collection development policy. https://library.du.edu/collections-archives/specialcollections/collectiondevelopment-policy.html

University of Georgia. (n.d.). Hargrett rare book and manuscript library - Collection development policy. http://www5.galib.uga.edu/scl/about/hargrett\%20collection\%20development\%20p olicy.pdf

University of Louisville. (n.d.). Collection policies. https://library.louisville.edu/archives/collection-policies

University of North Texas. (n.d.). Special collections collection development policy. https://library.unt.edu/policies/special-collections-collection-development/ University of Pennsylvania. (n.d.). Special collections: printed books collection development policy. https://www.library.upenn.edu/collections/policies/specialcollections-printed-books

University of Pennsylvania. (n.d.). Special collections: manuscripts collection development policy. https://www.library.upenn.edu/collections/policies/specialcollections-manuscripts

University of Regina. (n.d.). Special collections collection policy. https://uregina.libguides.com/c.php?g=606183\&p=4202172 University of Southern California. (n.d.). Rare books collection development policy. https://libraries.usc.edu/sites/default/files/rare-books-collection-development20190520.docx .pdf 


\section{THE VALUE OF A BOOK}

University of Virginia Library. (n.d.). Collection development policy. https://small.library.virginia.edu/collections/collection-development-policy/ Vanderbilt University. (n.d.). Collection development policy.

https://www.library.vanderbilt.edu/specialcollections/policies/collectiondevelopme nt.php 